\begin{tabular}{|c|c|}
\hline 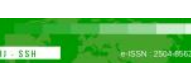 & Malaysian Journal of Social Sciences and Humanities (MJSSH) \\
\hline Malaysian Journal of & Volume 6, Issue 7, July 2021 \\
\hline (MJ - SSH) & e-ISSN : 2504-8562 \\
\hline & $\begin{array}{l}\text { Journal home page: } \\
\text { www.msocialsciences.com }\end{array}$ \\
\hline
\end{tabular}

\title{
Kesepaduan Nasional Penduduk Kawasan Rukun Tetangga di Malaysia
}

\author{
Beh Sang How ${ }^{1,2}$, Mohd Sobhi Ishak ${ }^{1}$, Pue Giok Hun'1, Mansor Mohd Noor1 \\ 1Institut Kajian Etnik (KITA), Universiti Kebangsaan Malaysia (UKM) \\ 2Jabatan Perpaduan Negara dan Integrasi Nasional (JPNIN)
}

Correspondence: Mohd Sobhi Ishak (msobhi@ukm.edu.my)

\begin{abstract}
Abstrak
Malaysia adalah negara yang dibina berasaskan integrasi. Usaha untuk memupuk dan mengukuhkan hubungan antara etnik ke arah perpaduan yang diidamkan sentiasa ditekankan dalam agenda pembangunan negara bangsa Malaysia. Untuk itu, program Rukun Tetangga telah dilancarkan pada tahun 1975 sebagai satu usaha kerajaan untuk memupuk perpaduan di peringkat akar umbi masyarakat. Setelah lebih empat dekad dibentuk, sejauh mana terbinanya kesepaduan nasional dalam kalangan penduduk Kawasan Rukun Tetangga (KRT) di seluruh negara? Satu kajian kuantitatif yang diadaptasikan daripada model Indeks Perpaduan Nasional (IPNas) 2018 telah dijalankan ke atas 585 orang penduduk KRT di seluruh negara melalui kaedah purposive sampling. Ujian ANOVA sehala digunakan untuk menentukan perbezaan di antara etnik bagi konstruk kesepaduan sosial dan etos bangsa yang berhubungan dalam membentuk kesepaduan nasional. Ujian regresi linear mudah diaplikasikan untuk menentukan hubungan di antara etos bangsa dan kesepaduan sosial. Dapatan kajian menunjukkan terdapat perbezaan antara etnik dalam beberapa dimensi kesepaduan sosial dan etos bangsa. Manakala etos bangsa dan kesepaduan sosial mempunyai hubungan yang signifikan dalam membentuk kesepaduan nasional dalam kalangan penduduk KRT. Dapat dirumuskan bahawa kedua-dua aspek kesepaduan sosial dan etos bangsa perlu digerakkan sederap dalam setiap langkah pihak kerajaan untuk memupuk perpaduan di peringkat akar umbi masyarakat, termasuklah menerusi program KRT yang meraikan kepelbagaian masyarakat multietnik Malaysia.
\end{abstract}

Kata kunci: kesepaduan nasional, Rukun Tetangga, hubungan antara etnik, masyarakat multietnik Malaysia

\section{National Cohesion Among The Residents of Rukun Tetangga Areas In Malaysia}

\begin{abstract}
Malaysia is constructed based on integration. The efforts to foster and strengthen inter-ethnic relations towards unity are always emphasized in the nation-building development agenda in Malaysia. To this end, the Rukun Tetangga programme was launched in 1975 as a government effort to foster unity at the grassroots level of society. More than four decades after its inception, how developed is the national cohesion among the residents of Rukun Tetangga (KRT) areas nationwide? A quantitative study that was adapted from the National Unity Index (IPNas) 2018 model, was conducted on 585 KRT residents in Malaysia selected via purposive sampling method. One -way ANOVA tests were used to determine interethnic differences for constructs of social cohesion and national ethos related in forming national cohesion. Simple linear regression is applied to determine the relationship between national ethos and
\end{abstract}


social cohesion. The findings of the study indicate that there are differences between ethnics in several dimensions of social cohesion and national ethos. Meanwhile, the national ethos and social cohesion have a significant relationship in forming national unity among the KRT population. It can be concluded that both aspects of social cohesion and the national ethos need to be included in the government's every move to foster unity at the grassroots level, including via the KRT program which celebrates ethnic diversity in Malaysian society.

Keywords: national unity, Rukun Tetangga, inter-ethnic relations, Malaysian multiethnic society

\section{Pengenalan}

Sebagai sebuah negara yang dibina berasaskan integrasi, usaha untuk memupuk dan mengukuhkan hubungan antara etnik ke arah perpaduan yang diidamkan sentiasa ditekankan dalam agenda pembangunan negara bangsa Malaysia (PERPADUAN \& KITA, 2019; Alatas, 1971). Usaha ini sememangnya mencabar memandangkan kepelbagaian etnik yang kompleks dalam masyarakat Malaysia. Pada tahun 2019, 32.7 juta orang penduduk Malaysia terdiri daripada 69.3 peratus kategori etnik Melayu, 22.8 peratus etnik Cina, 6.9 peratus etnik India dan 1.0 peratus etnik lain-lain (Jabatan Perangkaan Malaysia, 2019). Empat kategori ini seterusnya dapat diracikkan kepada kira-kira 70 kumpulan etnik dengan lebih 200 kumpulan sub-etnik, bahasa dan dialek di Malaysia (Shamsul, 2012). Selain etnisiti, kepelbagaian dalam masyarakat Malaysia juga dipengaruhi oleh sembilan defisit sosial yang lain iaitu agama, kelas sosial, pendidikan, bahasa, jurang generasi, gender, ideologi politik, ruang (bandar/desa) dan penggunaan media (PERPADUAN \& KITA, 2019). Kepelbagaian ini diraikan menerusi Perlembagaan Persekutuan di mana semua rakyat Malaysia dijamin perlindungan dan kebebasan untuk mempelajari dan mengamalkan bahasa, budaya dan agama masing-masing, seiring dengan kedudukan istimewa ketamadunan anak watan sebagai acuan pembinaan negara bangsa (Alatas, 1971). Keadaan yang kelihatannya paradoks ini menjadikan kejayaan masyarakat multietnik Malaysia hidup bersama dalam keadaan aman dan makmur, sering dijadikan contoh oleh negara-negara lain (Shamsul, 2012).

Keamanan dan kemakmuran yang dikecapi hari ini bukanlah satu kejayaan yang datang bergolek tanpa usaha. Sejak mencapai kemerdekaan pada tahun 1957, peristiwa 13 Mei 1969 dikatakan satu-satunya keganasan etnik berskala besar dan signifikan dalam sejarah pasca merdeka di Malaysia. Sehubungan itu, peristiwa tersebut dijadikan asas penting bagi pelaksanaan pelbagai dasar, projek dan inisiatif kerajaan untuk memastikan keseimbangan sosioekonomi dan mengurangkan jurang dalam hubungan antara etnik di Malaysia. Antara usaha terawal melalui Majlis Gerakan Negara (MAGERAN) yang ditubuhkan pada 17 Mei 1969 adalah dengan memperkenalkan ideologi kebangsaan iaitu Rukun Negara (Alatas, 1971), dan menubuhkan Majlis Perundangan Negara dan Jabatan Perpaduan Negara pada tahun 1970 (JPNIN, 2018). Skim Rukun Tetangga pula dilancarkan pada 1975 dengan matlamat khusus untuk menjaga keselamatan dan memupuk perpaduan etnik di peringkat akar umbi masyarakat. Skim tersebut kini dikenali sebagai Kawasan Rukun Tetangga (KRT) dan masih diteruskan di seluruh negara. Selain daripada usaha-usaha yang bersifat proaktif ini, kerajaan juga mengambil pendekatan pencegahan dengan memantau keadaan hubungan antara etnik dalam masyarakat semasa. Buat pertama kalinya pada tahun 2018, kerajaan menerusi Jabatan Perpaduan Negara dan Integrasi Nasional (PERPADUAN) dengan kerjasama Institut Kajian Etnik, Universiti Kebangsaan Malaysia (KITA-UKM) telah membangunkan Indeks Perpaduan Nasional (IPNas), yakni satu indeks yang khusus untuk mengukur tahap perpaduan dalam kalangan ahli masyarakat di Malaysia (PERPADUAN \& KITA, 2019).

Dalam tempoh 45 tahun penubuhannya, KRT telah berkembang dan berubah skopnya mengikut keperluan masyarakat dan situasi semasa. Sebagai contoh, konsep keselamatan di peringkat kawasan kejiranan yang menjadi fokus kepada KRT di awal penubuhannya pada tahun 1975, telah diubah kepada konsep kejiranan apabila keadaan menjadi semakin selamat, stabil dan bertambah baik dalam 1980-an. Pada tahun 2001, berlakunya pindaan kepada fokus KRT kepada aspek pembangunan komuniti, dan sekali lagi pada tahun 2010 untuk diselaraskan dengan Program Transformasi Kerajaan. Namun sepanjang perkembangan tersebut, KRT kekal dengan matlamat asalnya iaitu untuk menggalakkan 
hubungan antara etnik dan memupuk integrasi nasional dalam masyarakat multietnik Malaysia (Mohd Taib, 2009; Mahani, 2008; Alias, 2005; Rashid, 2004; Abd Hadi \& Norwahidah, 2013). Matlamat ini direalisasikan melalui aktiviti-aktiviti KRT yang dapat dibahagikan kepada lima teras iaitu keselamatan, perpaduan, pendidikan, ekonomi dan sara hidup, dan kualiti hidup (JPNIN, 2018). Pada tahun 2021 pula, fungsi dan peranan KRT telah dialihkan kepada "peneraju keharmonian, keselamatan dan perkhidmatan kepada komuniti" (Kementerian Perpaduan Negara, 2021, p. 24) menerusi Pelan Pemerkasaan Kepimpinan Komuniti Rukun Tetangga 2021-2030 yang dilancarkan pada bulan Februari 2021. Pelan Pemerkasaan ini dilaksanakan menerusi aktiviti-aktiviti komuniti yang terangkum dalam empat 'Gerak Kerja KRT' yang bertemakan kesejahteraan, keselamatan, kebersihan dan keindahan, dan kesihatan komuniti (JPNIN, 2021). Berdasarkan kepada Panduan Pengurusan dan Pentadbiran Rukun Tetangga (JPNIN, 2021), aktiviti atau program anjuran KRT boleh terdiri daripada pelbagai aspek kehidupan seperti perpaduan, keselamatan, ekonomi, pendidikan, alam sekitar, kebajikan dan khidmat komuniti, kesihatan, kesenian dan kebudayaan, agama, rekreasi dan sosial.

Konsensus umum para pengkaji bersetuju bahawa Kawasan Rukun Tetangga (KRT) bukan sahaja penting dalam menyumbang kepada peningkatan keselamatan, kestabilan dan kemakmuran kawasan kejiranan (Faris Isma et al., 2017; Norwahidah \& Novel, 2016), tetapi ia juga menjadi lokasi yang ideal dan tunjang kepada pemupukan perpaduan yang optimum di peringkat akar umbi masyarakat (Mohd Syariefudin, Mohd Mahadee \& Mansor, 2013; Budi Anto et al., 2020). Sungguhpun begitu, konsensus tersebut adalah terhasil daripada kajian-kajian lepas yang dijalankan di peringkat kawasan kejiranan, daerah atau negeri tertentu sahaja. Dalam konteks ini, kajian IPNas 2018 merupakan satu-satunya kajian terkini mengenai perpaduan yang menyeluruh dan melibatkan sebahagian besar KRT di seluruh negara.

Pasca kajian IPNas 2018, masyarakat multietnik Malaysia berhadapan dengan cabaran-cabaran baharu. Di peringkat dalaman negara, tahun 2019 telah digelar oleh Mustafa (2020) sebagai "...a chaotic year of party-political and electoral fatigue, social discontent, and economic slowdown...” (p. 100). Ini dapat dilihat daripada isu-isu yang tular dalam media sosial dalam tempoh 2018-2019 seperti ICERD, UEC, pendatang tanpa izin; percaturan parti politik, prestasi Kerajaan Persekutuan, perletakan jawatan Yang di-Pertuan Agong XV, tuduhan rasuah pemimpin negara dan isu 1MDB, persoalan ekonomi seperti peningkatan kos sara hidup dan kualiti hidup (Prashanta, 2018; Kartini \& Suraiya, 2019; Lee, 2018; Ehmer \& Kothari, 2020; Franck, 2019; Ufen, 2020; Mustafa, 2020). Mengambil kira keadaan seperti di atas, satu kajian telah dijalankan untuk mengkaji sejauh mana terbinanya kesepaduan nasional dalam kalangan penduduk KRT di Malaysia pada pasca IPNas 2018.

\section{Kesepaduan Nasional}

Walaupun perpaduan dalam masyarakat multietnik Malaysia telah menjadi matlamat penting dalam agenda pembangunan negara semenjak daripada Rancangan Malaysia Kedua (1970-1974) (Wan Humaiza, Gill \& Ismi 2016), istilah 'perpaduan' itu sendiri tidak dibincang dan didefinisikan dengan jelas dalam dokumen dan pelaksanaan oleh kerajaan. Menurut Shamsul (2014), apa yang lazim dilakukan oleh kerajaan untuk mencerminkan perpaduan di Malaysia ialah dengan menyerlahkan bentuk perpaduan yang ideal yang diidamkan iaitu 'perpaduan dalam kesatuan' (unity in uniformity). Ini digambarkan melalui ucapan atau ungkapan yang bersifat patriotik seperti slogan 'Malaysia Truly Asia' dan '1Malaysia', atau melalui representasi visual yang meraikan kepelbagaian, misalnya gambar masyarakat, sambutan perayaan, festival makanan dan sebagainya, yang sentiasa terdiri daripada wakil-wakil dan budaya-budaya etnik yang pelbagai. Representasi secara simplistik, abstrak dan subjektif sebegini dikenal pasti sebagai perpaduan dalam bentuk 'kefahaman awal' oleh Mohd Sobhi (2021). Menurut beliau, kefahaman sebegini berlaku dengan ketara dari tahun 1970-1974 apabila kerajaan mewujudkan pelbagai tindakan segera dalam menangani krisis dalam hubungan antara etnik pasca Tragedi 13 Mei 1969. Selepas dari itu sehingga ke tahun 2013, fokus kerajaan kepada pembangunan ekonomi melalui Dasar Ekonomi Baharu (DEB) yang distruktur dalam Rancangan-Rancangan Malaysia setiap lima tahun kerana berpandangan bahawa pengurusan dan pembangunan ekonomi akan turut meningkatkan perpaduan rakyat. Walau bagaimanapun, hal ini telah menimbulkan satu cabaran analitikal utama bagi ramai penyelidik dan pembuat dasar di Malaysia untuk menghurai dan mengukur perpaduan dalam masyarakat. Dalam tahun 2013, idea perpaduan dalam bentuk 'kefahaman terkini' telah diperkenalkan 
melalui Majlis Konsultatif Perpaduan Negara di mana ianya lebih berfokus dengan adanya matlamat, pelan tindakan terancang, dan pencapaian yang boleh diukur (PERPADUAN \& KITA, 2019; Mohd Sobhi, 2021).

Perpaduan dalam bentuk kefahaman terkini berasaskan kepada pemikiran Profesor Ulung Dr. Shamsul Amri Baharuddin (Shamsul \& Anis, 2014) seterusnya membolehkan inti sari kata dasar 'padu' dibezakan kepada tiga bentuk pengertian iaitu 'perpaduan', 'kesepaduan', dan 'penyatupaduan' (Shamsul, 2014; Mohd Sobhi, 2021). Dalam konteks ilmu sosiologi, konsep 'perpaduan' (unity) merujuk kepada terbentuknya satu entiti daripada penyatuan kumpulan-kumpulan etnik yang pelbagai secara bersatupadu dan seragam. Dalam konteks pembinaan negara bangsa, perpaduan adalah satu abstraksi yang dibayangkan sebagai matlamat akhir kepada semua usaha membentuk satu bangsa Malaysia. Sebagai satu sasaran yang ideal, 'perpaduan' hanya wujud dalam bentuk idea dan tidak dapat direalisasikan dalam realiti sebenar. Sebaliknya, apa yang dialami dalam kehidupan sosial ialah 'kesepaduan' (cohesion). Konsep ini didefinisikan sebagai tahap pencapaian perpaduan semasa yang boleh diukur berdasarkan pelbagai komponen. Manakala, usaha-usaha terancang yang dilakukan dalam proses untuk mengangkat 'kesepaduan' sehingga ke tahap tercapainya 'perpaduan' yang diidamkan adalah merujuk kepada konsep 'penyatupaduan' (reconciliation). Ini termasuklah melalui penyediaan 'tapak-tapak integrasi' dalam masyarakat seperti program Kawasan Rukun Tetangga.

Indeks Perpaduan Nasional (IPNas) yang dibangunkan pada tahun 2018 dan diterbitkan pada tahun 2019 hasil kerjasama antara PERPADUAN dengan pasukan perunding daripada Institut Kajian Etnik (KITA) merupakan satu kajian yang julung kalinya menggunakan tiga konsep teras 'perpaduan', 'kesepaduan' dan 'penyatupaduan'. Nilai indeks ini diukur berdasarkan nilai varian keseluruhan yang terkumpul dalam 'konstruk' yang merujuk kepada konsep sosial “...yang dioperasionalkan supaya boleh diukur...” (PERPADUAN \& KITA, 2019, p. 6). Model kajian IPNas 2018 terbina daripada pengukuran hubungkait tujuh konstruk, iaitu 'hubungan sosial rentas etnik' (HSRE), 'tahap keetnikan' (TK), 'batas etnik' (BE), 'tadbir urus dan pembangunan' (TU\&P), 'etos bangsa' (EB), 'kesepaduan sosial' (KS) dan 'detik perpaduan' (DP) (PERPADUAN \& KITA, 2019). Secara keseluruhannya, nilai IPNas bagi tahun 2018 didapati berada pada kadar 0.567 yang dianggap sederhana tinggi berdasarkan skala 0 hingga 1 . Menurut Cohen (1990), skala indeks ini merupakan petunjuk yang sesuai bagi kajian tingkah laku manusia. Dalam indeks ini, nilai tersebut menunjukkan bahawa tahap perpaduan di Malaysia adalah stabil walaupun defisit sosial masih berterusan dan muncul sekali sekala (PERPADUAN \& KITA, 2019).

Rajah 1 menunjukkan teras utama IPNas 2018 (PERPADUAN \& KITA, 2019). Perpaduan diidamkan diukur menggunakan konstruk detik perpaduan. Kesepaduan dicapai adalah merujuk kepada pencapaian kesepaduan nasional yang menjadi tunjang perbincangan artikel ini yang terbina hasil pembentukan hubungan di antara konstruk etos bangsa dan kesepaduan sosial. Inilah teras pengukuran yang ingin dicapai melalui IPNas iaitu mengukur perpaduan rakyat berdasarkan pencapaian tahap kesepaduan nasional. Penyatupaduan yang diusahakan adalah merupakan usaha penyatupaduan etnik berasaskan tiga konstruk etnik iaitu tahap keetnikan, batas etnik dan hubungan sosial rentas etnik. Ia disokong oleh tadbir urus kerajaan dan pembangunan sebagai tapak integrasi menggunakan formula tawar-menawar, perundingan dan mediasi.

Fokus perbincangan dalam artikel ini adalah terbatas kepada skop penelitian kesepaduan nasional dalam konteks etos bangsa dan kesepaduan sosial sahaja. Seperti yang digambarkan dalam Rajah 1, 'kesepaduan nasional' (national cohesion) merupakan satu konsep terbitan yang muncul apabila pemboleh ubah kesepaduan sosial berinteraksi dengan pemboleh ubah etos bangsa (Mansor, 2012). Dalam perkataan lain, walaupun kedua-duanya merujuk kepada tahap kemajuan (progress) ke arah perpaduan yang diimpikan, kesepaduan sosial adalah subset kepada kesepaduan nasional. Dalam kajian ini, kesepaduan sosial (social cohesion) merujuk kepada pemerihalan elemen-elemen sepunya yang wujud dalam masyarakat hasil daripada proses penyatupaduan yang diusahakan. Elemen-elemen sepunya yang dimaksudkan termasuklah rasa kekitaan, penyertaan, kesamarataan, pengiktirafan, legitimasi dan keterangkuman dalam kehidupan seharian. Manakala, konsep etos bangsa merupakan ringkasan daripada perkataan 'etos nasional bangsa Malaysia' yang boleh difahami sebagai "ciri-ciri unik masyarakat setempat yang mengikat seseorang individu dengan individu yang lain, dan yang mengikat individu dengan negara" (Mohd Mahadee, 2015, p. 383). Etos bangsa juga dapat diringkaskan sebagai 
merujuk kepada identiti warga negara atau jati diri kebangsaan yang dapat dikenal pasti melalui ciri-ciri seperti semangat patriotisme, taat setia, dan cinta kepada negara. Dalam kajian ini, kesepaduan nasional merupakan gambaran pencapaian perpaduan yang terbina dalam diri setiap responden kajian sebagai manifestasi biografi perpaduan dalam diri mereka.

Rajah 1: Teras Utama Indeks Perpaduan Nasional 2018

\section{TERAS UTAMA INDEKS PERPADUAN NASIONAL 2018}
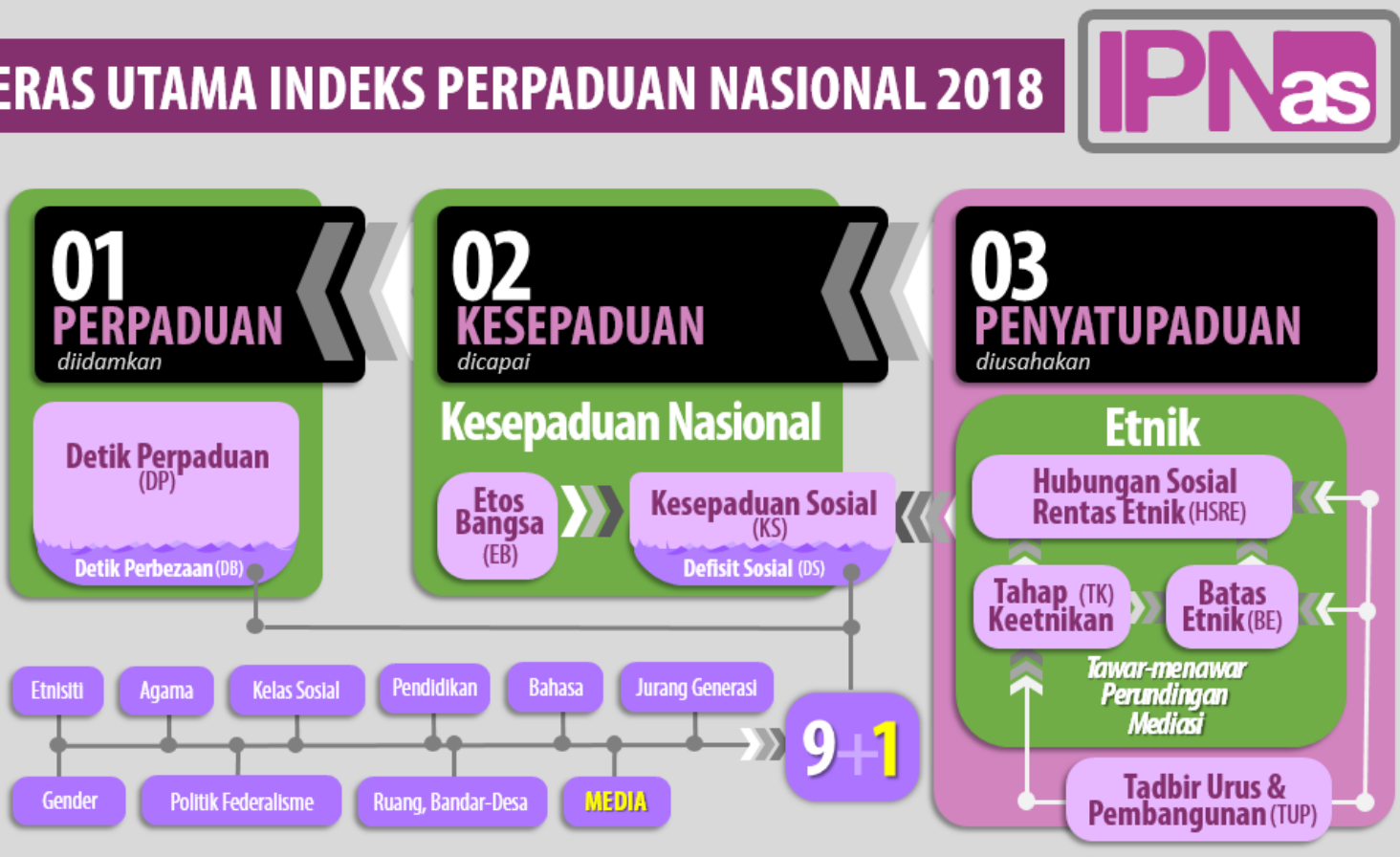

diusahakan

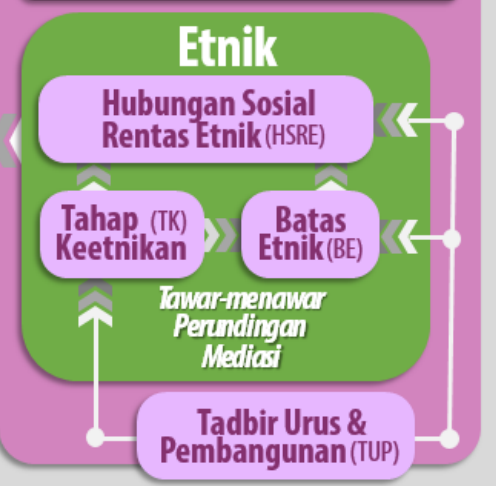

Sumber: PERPADUAN \& KITA (2019)

\section{Metod Kajian}

Kajian ini menggunakan pendekatan kuantitatif yang sesuai untuk menyelidik dan menganalisis masyarakat dalam skop kawasan yang luas (Babbie, 2010). Ini penting memandangkan skop kajian ini adalah penduduk KRT di seluruh negara. Responden dipilih menggunakan kaedah purposive sampling daripada kalangan penduduk dalam kejiranan KRT yang terdiri daripada pelbagai etnik, latar belakang dari setiap negeri dan Wilayah Persekutuan di Malaysia (Jadual 1).

Jadual 1: Taburan Responden Mengikut Negeri $(\mathrm{n}=585)$

\begin{tabular}{lcc}
\hline \multirow{2}{*}{ Negeri } & \multicolumn{2}{c}{ Responden } \\
\cline { 2 - 3 } & Bilangan & Peratus (\%) \\
\hline Wilayah Persekutuan Kuala Lumpur & 75 & 12.8 \\
Sarawak & 65 & 11.1 \\
Sabah & 59 & 10.1 \\
Pulau Pinang & 56 & 9.6 \\
Negeri Sembilan & 41 & 7.0 \\
Selangor & 40 & 6.8 \\
Perak & 35 & 6.0 \\
Melaka & 34 & 5.8 \\
Kelantan & 33 & 5.6 \\
Pahang & 33 & 5.6 \\
Johor & 26 & 4.4
\end{tabular}


DOI: https://doi.org/10.47405/mjssh.v6i7.821

\begin{tabular}{lcc}
\hline \multirow{2}{*}{ Negeri } & \multicolumn{2}{c}{ Responden } \\
\cline { 2 - 3 } & Bilangan & Peratus (\%) \\
\hline Perlis & 25 & 4.3 \\
Kedah & 23 & 3.9 \\
Terengganu & 20 & 3.4 \\
Wilayah Persekutuan Labuan & 10 & 1.7 \\
Wilayah Persekutuan Putrajaya & 10 & 1.7 \\
\hline Jumlah & $\mathbf{5 8 5}$ & $\mathbf{1 0 0 . 0}$ \\
\hline
\end{tabular}

Proses kutipan data melalui borang soal selidik ini telah dilaksanakan pada awal bulan Disember 2019 hingga 31 Januari 2020. Pada pertengahan bulan Mac 2020, sebanyak 587 set borang soal selidik telah berjaya dikumpul kembali. Daripada jumlah tersebut, sebanyak 585 set borang soal selidik yang lengkap diisi telah berjaya dikumpulkan untuk dianalisis $(n=585)$ daripada 600 set borang soal selidik yang diedarkan di seluruh negara. Manakala dua set borang soal selidik didapati tidak dijawab dengan lengkap oleh responden, maka dua set borang soal selidik tersebut dikira sebagai rosak dan telah ditolak. Didapati juga sebanyak 13 set borang soal selidik telah hilang dan tidak dikembalikan.

Selain daripada latar belakang responden, pembinaan borang soal selidik turut mengambil kira data yang diperlukan untuk mengukur tujuh konstruk iaitu Hubungan Sosial Rentas Etnik (HSRE), Tadbir Urus Kerajaan dan Pembangunan (TU\&P), Kesepaduan Sosial (KS), Etos Bangsa (EB), Naratif Negara Bangsa (NNB), Literasi Politik (LP) dan Media Sosial (MS). Walau bagaimanapun, artikel ini memberikan tumpuan kepada dua konstruk sahaja iaitu Kesepaduan Sosial (KS) dan Etos Bangsa (EB).

Kesepaduan Sosial (KS) merupakan proses dan tindakan yang melibatkan komitmen dan keinginan untuk hidup bersama dalam suasana harmoni oleh kumpulan-kumpulan sosial yang berbeza etika dan peradabannya dengan cara membina jambatan kesepakatan sosial antara mereka (Jenson, 1998; Bernard, 1999; Mansor, 2012). Dalam kajian ini elemen-elemen sepunya yang merentas garis etnik penduduk KRT dalam kehidupan seharian mereka seperti rasa kekitaan, keterangkuman, penyertaan, pengiktirafan, legitimasi dan kesamarataan. Konstruk KS ini diukur menggunakan 24 item soalan berdasarkan skala likert 5 tahap (1=Sangat Tidak Setuju hingga 5=Sangat Setuju).

Etos Bangsa (EB) merupakan kependekan dari konsep 'Etos Nasional Bangsa Malaysia' yang merujuk kepada pembentukan memori dan identiti kolektif yang menjadi acuan kepada pembentukan karekter nasional di kalangan anggota masyarakat. Etos Bangsa perlu mengambil kira bentuk hubungan etnik yang terjalin dalam masyarakat multi-etnik selama ini dan hubungan inilah yang menjadi penentu kepada proses pembinaan negara bangsa (Mansor, Abdul Rahman, \& Mohamad Ainuddin, 2006). Dalam konteks Malaysia, Etos Bangsa terdiri daripada tujuk komponen iaitu rasa keterikatan bersama; rasa keterikatan emosi dengan negara yang tinggi; inginkan perkongsian masa depan yang baik; perkongsian nilai sepunya; kesetiaan; komitmen dan perkongsian sejarah (Mahathir, 1992; PERPADUAN \& KITA, 2019). Pembentukan ciri kolektif nasional yang mengandungi semangat patriotisme, taat setia dan cinta kepada negara dalam amalan seharian penduduk KRT yang dikenal pasti melalui dimensi perkongsian sejarah, perasaan kekitaan, perkongsian nilai, perkongsian masa hadapan, kesetiaan, keterikatan emosi negara dan komitmen. Sebanyak 14 item soalan digunakan untuk mengukur konstruk Etos Bangsa berdasarkan skala likert 5 tahap (1=Sangat Tidak Setuju hingga 5=Sangat Setuju).

Data yang dikumpulkan kemudiannya dimasukkan dan dianalisis melalui analisis statistik deskriptif menggunakan frekuensi dan peratus. Analisis statistik inferensi pula menggunakan ujian statistik ANOVA Sehala untuk menentukan perbezaan signifikan antara etnik terhadap konstruk kajian dan analisis regresi linear mudah untuk menentukan hubungan antara etos bangsa terhadap kesepaduan sosial. 


\section{Dapatan Kajian dan Perbincangan}

\section{Latar Belakang Responden}

Majoriti responden yang terlibat dalam kajian ini adalah lelaki iaitu seramai 351 orang $(60.5 \%)$ dan selebihnya adalah 231 orang wanita (39.5\%). Etnik Melayu adalah kumpulan majoriti yang terlibat dalam kajian ini iaitu seramai 242 orang (41.4\%) dan diikuti oleh etnik Cina seramai 150 orang (25.6\%), etnik India seramai 116 orang (19.8\%) dan etnik Bumiputera Sabah dan Sarawak seramai 77 orang (13.2\%). Senario ini bertepatan dengan keadaan sebenar komposisi penduduk mengikut etnik di Malaysia masa kini di mana etnik Melayu merupakan majoriti penduduk dan diikuti dengan etnik Cina, etnik India dan lain-lain etnik (Jabatan Perangkaan Malaysia, 2019).

Dari segi komposisi agama pula, seramai 290 orang responden beragama Islam (49.6\%), 136 orang responden beragama Buddha (23.2\%), 105 orang responden beragama Hindu (17.9\%), 52 orang responden beragama Kristian (8.9\%); hanya seorang beragama Sikh $(0.2 \%)$ dan seorang lagi beragama Bahai $(0.2 \%)$. Pengkaji mendapati bahawa seorang responden daripada kumpulan reponden etnik Cina adalah beragama Islam dan tiga orang penduduk daripada kumpulan responden etnik India beragama Buddha.

Daripada jumlah keseluruhan responden tersebut, majoriti responden (70.9\%) mempunyai tahap pendidikan peringkat Pendidikan Menengah iaitu di Sekolah Menengah Atas (SPM / STPM) dan Kolej atau Politeknik (Sijil atau Diploma). Daripada segi pekerjaan pula, 45.8\% responden terlibat dalam kajian ini adalah terdiri daripada kategori Pekerjaan Menengah seperti guru, teknikal, kerani, jurujual atau Peruncit. Manakala 68.2\% responden berpendapatan RM3,000 dan ke bawah di kategori Pendapatan Rendah.

Rumusannya, dapatan data daripada taburan profil responden dalam kajian ini adalah agak seimbang yang mewakili relatif sosial sedia ada di masyarakat multietnik Malaysia. Jumlah responden yang diperolehi juga telah menggambarkan komposisi penduduk mengikut etnik di Malaysia iaitu majoriti penduduk adalah etnik Melayu dan diikuti dengan etnik Cina, etnik India dan etnik lain-lain.

\section{Kesepaduan Sosial (KS)}

Terdapat perbezaan yang signifikan antara etnik Melayu, Cina, India dan Bumiputera Sabah Sarawak bagi setiap dimensi kesepaduan sosial iaitu rasa kekitaan $(\mathrm{F}(3,581)=6.74, \mathrm{p}=.000$, keterangkuman $(\mathrm{F}(3,581)=2.91, \mathrm{p}=.000$, penyertaan $(\mathrm{F}(3,581)=5.51, \mathrm{p}=.001$, pengiktirafan $(\mathrm{F}(3,581)=7.65, \mathrm{p}=$ .000 , dan kesamaan $(\mathrm{F}(3,581)=3.32, \mathrm{p}=.020$ seperti yang ditunjukkan oleh nilai ANOVA Sehala.

Jadual 2: Min, Sisihan Piawai, dan Analisis ANOVA Sehala Dimensi-Dimensi Kesepaduan Sosial

\begin{tabular}{|c|c|c|c|c|c|c|c|c|c|c|c|}
\hline \multirow{2}{*}{ Dimensi } & \multicolumn{2}{|c|}{ Melayu } & \multicolumn{2}{|c|}{ Cina } & \multicolumn{2}{|c|}{ India } & \multicolumn{2}{|c|}{ Bumi SS } & \multirow{2}{*}{$F(3,581)$} & \multirow[b]{2}{*}{$\mathbf{p}$} & \multirow{2}{*}{$\eta^{2}$} \\
\hline & $\mathbf{M}$ & SP & $\mathbf{M}$ & SP & $\mathbf{M}$ & SP & $\mathbf{M}$ & SP & & & \\
\hline RK & 3.85 & .53 & 3.88 & .51 & 3.93 & .47 & 4.14 & .43 & $6.74 * *$ & .000 & .033 \\
\hline KT & 3.59 & .67 & 3.44 & .74 & 3.40 & .79 & 3.60 & .63 & $2.91 * *$ & .034 & .014 \\
\hline PY & 3.92 & .59 & 3.97 & .55 & 3.91 & .49 & 4.19 & .41 & $5.51 * *$ & .001 & .028 \\
\hline PI & 3.56 & .59 & 3.69 & .54 & 3.74 & .58 & 3.89 & .50 & $7.65^{* *}$ & .000 & .038 \\
\hline LG & 3.58 & .53 & 3.62 & .58 & 3.59 & .56 & 3.72 & .58 & 1.42 & .235 & .007 \\
\hline $\mathrm{KM}$ & 3.78 & .63 & 3.63 & .61 & 3.74 & .58 & 3.88 & .59 & $3.32 * *$ & .020 & .017 \\
\hline
\end{tabular}

Walau bagaimanapun, dimensi legitimasi $(\mathrm{F}(3,581)=1.42, \mathrm{p}=.235$ tidak menunjukkan perbezaan yang signifikan antara etnik. Sungguhpun terdapat perbezaan antara etnik bagi dimensi-dimensi yang dinyatakan, namun impak daripada kesan perbezaan ini adalah kecil berdasarkan nilai eta kuasa dua $\left(\eta^{2}\right)$ 
yang diperolehi. Bagi dimensi keterangkuman dan kesamaan, nilai eta kuasa dua $\left(\eta^{2}\right)$ di bawah nilai petunjuk 0.2 menunjukkan kesan perbezaan ini tidak memberi impak langsung. Terdapat kecenderungan kesan perbezaan ini bergerak ke tahap sederhana (0.5) bagi dimensi pengiktirafan $(0.38)$ dan penyertaan (0.28). Hal ini menunjukkan kedua-dua dimensi ini berupaya menggugat kesepaduan sosial dalam masyarakat. Dapatan ini selari dengan dapatan Indeks Perpaduan Nasional (IPNas) 2018 yang menunjukkan bahawa kesepaduan sosial adalah tinggi dalam kalangan masyarakat. Namun, ia direncatkan oleh tahap penyertaan politik dan NGO yang rendah dalam membina kesepaduan sosial dalam kalangan etnik Melayu dan India.

Berdasarkan dapatan ini, ujian post hoc Tukey dilaksanakan untuk mengetahui kumpulan etnik yang berbeza bagi setiap dimensi konstruk kesepaduan sosial. Bagi dimensi rasa kekitaan, etnik Melayu ($.289 *)$, Cina $(-.257 *)$ dan India (-.209*) didapati berbeza pandangan secara signifikan berbanding etnik Bumiputera Sabah dan Sarawak pada tahap signifikan p<.05. Dapatan ini menunjukkan bahawa etnik Sabah dan Sarawak lebih tinggi rasa kekitaan mereka kerana ciri kepelbagaian asal-usul etnik masih dipertahankan, menyambut baik pelbagai program sosio-budaya yang diadakan, menunjukkan simpati kepada kenalan etnik dalam hal kematian dan menerima pembinaan taman perumahan berasaskan percampuran pelbagai etnik. Oleh sebab itulah, etnik Bumiputera Sabah dan Sarawak didapati lebih akrab antara satu sama lain yang melambangkan kesepaduan sosial yang baik dalam diri mereka. Dapatan ini adalah selari dengan hasil kajian Indeks Perpaduan Nasional 2018 (PERPADUAN \& KITA, 2019) yang menunjukkan etnik Sabah dan Sarawak lebih tinggi rasa kekitaan mereka.

Bagi dimensi keterangkuman, kesemua etnik tidak berbeza pandangan secara signifikan antara satu sama lain pada tahap $\mathrm{p}<.05$. Dapatan ini menunjukkan semua etnik menzahirkan pandangan yang sama bahawa kerajaan telah membuka ruang yang sama kepada semua etnik dalam bentuk peluang pekerjaan di sektor awam, peluang memiliki rumah, peluang pendidikan di institusi pengajian tinggi awam, dan bantuan daripada pihak kerajaan kepada semua rakyat.

Bagi dimensi penyertaan iaitu penyertaan dalam hal berkaitan politik dan NGO, etnik India $\left(-.281^{*}\right)$, Melayu $\left(-.272^{*}\right)$ dan Cina $\left(-.221^{*}\right)$ didapati berbeza pandangan secara signifikan berbanding etnik Bumiputera Sabah dan Sarawak. Hal ini menunjukkan bahawa etnik Bumiputera Sabah dan Sarawak mempunyai kecenderungan tinggi untuk mengundi mana-mana calon atau parti politik yang mereka gemari, bebas membincangkan hal politik, menyertai aktiviti persatuan dan badan kebajikan yang disertai pelbagai kaum dan bebas menyertai mana-mana NGO yang mereka mahu. Kesemua ini menjadi petunjuk penting kepada peningkatan kesepaduan sosial dalam masyarakat. Dapatan ini adalah selari dengan hasil kajian Indeks Perpaduan Nasional 2018 (PERPADUAN \& KITA, 2019) yang menunjukkan bahawa etnik Sabah dan Sarawak lebih menunjukkan rasa kekitaan mereka secara konsisten dalam hal perjuangan politik dan penyertaan mereka dalam persatuan, badan kebajikan dan NGO.

Bagi dimensi pengiktirafan, etnik Melayu didapati berbeza pandangan secara signifikan berbanding etnik Bumiputera Sabah dan Sarawak (-.330*) dan India (-.182*). Dapatan ini menunjukkan bahawa etnik Sabah dan Sarawak menyokong tinggi usaha pengiktirafan dengan cara menunjukkan penghargaan kepada rakyat yang berjasa, mengurus tadbir dan membangunkan negara dengan baik, mengiktiraf simbol-simbol agama lain, dan menerima perbezaan pendapat antara etnik sebagai amalan sihat. Pengiktirafan ini akhirnya telah menyumbang kepada peningkatan kesepaduan sosial dalam diri mereka. Dapatan ini selari dengan hasil kajian Indeks Perpaduan Nasional 2018 (PERPADUAN \& KITA, 2019) yang menunjukkan bahawa etnik Bumiputera Sabah dan Sarawak serta India melihat keperluan kepada elemen-elemen pengiktirafan ini sebagai petunjuk kepada peningkatan kesepaduan sosial.

Dalam konteks legitimasi, kesemua etnik tidak berbeza pandangan secara signifikan terhadap beberapa elemen yang dikemukakan. Mereka bersepakat bahawa janji dan manifesto ahli politik bukan satu ketetapan mutlak, wujud undang-undang berkaitan agama yang berbeza di negara ini yang perlu dihormati, perlunya berwaspada apabila menerima berita-berita kepincangan tadbir urus kerajaan dan NGO masih diberikan peluang yang terhad. Hal ini menunjukkan masyarakat mempunyai tahap kefahaman yang baik hingga akhirnya menjelaskan kepada pencapaian tahap kesepaduan sosial yang tinggi. 
DOI: https://doi.org/10.47405/mjssh.v6i7.821

Analisis terhadap dimensi terakhir iaitu kesamaan mendapati kesemua etnik boleh menerima konsep kesamaan ini. Walau bagaimanapun, wujud perbezaan pandangan yang signifikan antara etnik Cina dan Bumiputera Sabah dan Sarawak (-.250*). Berdasarkan analisis ini, etnik Bumiputra Sabah dan Sarawak lebih merasakan bahawa pekerja asing telah merampas peluang pekerjaan rakyat tempatan, peluang pengajian tinggi kepada pelajar cemerlang, bantuan pihak berkuasa mudah diperolehi dan jurang kemiskinan antara etnik masih ketara. Hal inilah yang berkemungkinan menunjukkan perjuangan hak oleh etnik Bumiputera Sabah dan Sarawak lebih tinggi berbanding etnik Cina dan etnik-etnik lain. Dapatan ini bertepatan dengan hasil kajian Indeks Perpaduan Nasional 2018 (PERPADUAN \& KITA, 2019) yang menunjukkan bahawa kesamaan adalah isu yang masih diperjuangkan di negara ini khususnya oleh etnik Sabah dan Sarawak.

Jadual 3: Keputusan Ujian Post Hoc Tukey Konstruk Kesepaduan Sosial mengikut Etnik

\begin{tabular}{|c|c|c|c|c|c|}
\hline Dimensi & Etnik & Etnik & Perbezaan Min & Ralat Piawai & Signifikan \\
\hline \multirow[t]{6}{*}{ Rasa Kekitaan } & Melayu & Cina & -.030 & .051 & .936 \\
\hline & Cina & India & -.049 & .062 & .855 \\
\hline & India & Bumi SS & $-.209 *$ & .074 & .024 \\
\hline & Melayu & India & -.080 & .056 & .492 \\
\hline & Cina & Bumi SS & $-.257 *$ & .070 & .001 \\
\hline & Melayu & Bumi SS & $-.289 *$ & .065 & .000 \\
\hline \multirow[t]{6}{*}{ Keterangkuman } & Melayu & Cina & .149 & .074 & .182 \\
\hline & Cina & India & .043 & .088 & .960 \\
\hline & India & Bumi SS & -.207 & .104 & .193 \\
\hline & Melayu & India & .192 & .080 & .078 \\
\hline & Cina & Bumi SS & -.163 & -.164 & .352 \\
\hline & Melayu & Bumi SS & -.015 & -.015 & .998 \\
\hline \multirow[t]{6}{*}{ Penyertaan } & Melayu & Cina & -.051 & .056 & .801 \\
\hline & Cina & India & .060 & .067 & .809 \\
\hline & India & Bumi SS & $-.281 *$ & .079 & .002 \\
\hline & Melayu & India & .009 & .061 & .999 \\
\hline & Cina & Bumi SS & $-.221 *$ & .076 & .018 \\
\hline & Melayu & Bumi SS & $-.272 *$ & .071 & .001 \\
\hline \multirow[t]{6}{*}{ Pengiktirafan } & Melayu & Cina & -.130 & .059 & .119 \\
\hline & Cina & India & -.052 & .069 & .877 \\
\hline & India & Bumi SS & -.147 & .083 & .288 \\
\hline & Melayu & India & $-.182 *$ & .064 & .022 \\
\hline & Cina & Bumi SS & -.199 & .079 & .058 \\
\hline & Melayu & Bumi SS & $-.330 *$ & .074 & .000 \\
\hline \multirow{6}{*}{ Legitimasi } & Melayu & Cina & -.367 & .058 & .921 \\
\hline & Cina & India & .032 & .069 & .967 \\
\hline & India & Bumi SS & -.141 & .082 & .314 \\
\hline & Melayu & India & -.005 & .063 & 1.00 \\
\hline & Cina & Bumi SS & -.108 & .078 & .505 \\
\hline & Melayu & Bumi SS & -.146 & .073 & 191 \\
\hline \multirow[t]{6}{*}{ Kesamaan } & Melayu & Cina & .151 & .063 & .081 \\
\hline & Cina & India & -.111 & .075 & .451 \\
\hline & India & Bumi SS & -.138 & .089 & .410 \\
\hline & Melayu & India & .039 & .069 & .939 \\
\hline & Cina & Bumi SS & $-.250 *$ & .085 & .019 \\
\hline & Melayu & Bumi SS & -.099 & .080 & .601 \\
\hline
\end{tabular}

Nota: Bumi SS = Bumiputera Sabah dan Sarawak 


\section{Etos Bangsa (EB)}

Jadual 4 menunjukkan bahawa terdapat perbezaan yang signifikan antara etnik bagi dimensi perkongsian sejarah $(\mathrm{F}(3,581)=3.46, \mathrm{p}=.016$, perasaan kekitaan $(\mathrm{F}(3,581)=4.71, \mathrm{p}=.003$ dan kesetiaan $(\mathrm{F}(3,581)$ $=5.07, \mathrm{p}=.002$ dan komitmen $(\mathrm{F}(3,581)=2.86, \mathrm{p}=.036$, seperti yang ditunjukkan oleh nilai ANOVA Sehala. Dimensi perkongsian masa depan $(\mathrm{F}(3,581)=2.44, \mathrm{p}=.064$ dan keterikatan emosi negara $(\mathrm{F}(3,581)=1.71, \mathrm{p}=.163$ tidak menunjukkan perbezaan yang signifikan antara etnik. Sungguhpun terdapat perbezaan antara etnik bagi dimensi-dimensi yang dinyatakan, namun impak perbezaan ini adalah sangat kecil berdasarkan nilai eta kuasa dua $\left(\eta^{2}\right)$ sangat rendah daripada 0.2. Ketiga-tiga dimensi yang signifikan ini iaitu perkongsian sejarah, perasaan kekitaan, kesetiaan dan komitmen merupakan petunjuk penting kepada pencapaian nilai etos nasional bangsa Malaysia berasaskan identiti dan jati diri rakyat yang telah terbentuk sebagai biografi dalam diri masing-masing. Dapatan ini selari dengan dapatan Indeks Perpaduan Nasional (IPNas) 2018 yang menunjukkan bahawa kesepaduan sosial adalah tinggi dalam kalangan masyarakat. Namun, ia direncatkan oleh tahap penyertaan politik dan NGO yang rendah dalam membina kesepaduan sosial dalam kalangan etnik Melayu dan India.

Jadual 4: Min, Sisihan Piawai, dan Analisis ANOVA Sehala Dimensi-Dimensi Etos Bangsa

\begin{tabular}{|c|c|c|c|c|c|c|c|c|c|c|c|}
\hline \multirow[b]{2}{*}{ Dimensi } & \multicolumn{2}{|c|}{ Melayu } & \multicolumn{2}{|l|}{ Cina } & \multicolumn{2}{|c|}{ India } & \multicolumn{2}{|c|}{ Bumi SS } & \multirow{2}{*}{$F(3,581)$} & \multirow[b]{2}{*}{$\mathbf{p}$} & \multirow{2}{*}{$\eta^{2}$} \\
\hline & M & SP & M & SP & M & SP & M & SP & & & \\
\hline PSJ & 3.78 & .72 & 3.88 & .64 & 3.91 & .65 & 4.05 & .61 & $3.46 * *$ & .016 & .018 \\
\hline PKT & 4.18 & .70 & 4.10 & .66 & 4.04 & .68 & 4.39 & .63 & $4.71 * *$ & .003 & .024 \\
\hline PMD & 3.95 & .78 & 3.80 & .86 & 3.96 & .74 & 4.08 & .68 & 2.44 & .064 & .012 \\
\hline KST & 4.19 & .72 & 4.07 & .69 & 4.31 & .61 & 4.42 & .59 & $5.07^{*}$ & .002 & .003 \\
\hline KEN & 4.24 & .72 & 4.17 & .71 & 4.27 & .63 & 4.39 & .65 & 1.71 & .163 & .001 \\
\hline KMT & 4.18 & .77 & 4.09 & .69 & 4.25 & .64 & 4.36 & .59 & $2.86^{*}$ & .036 & .014 \\
\hline
\end{tabular}

$* * \mathrm{p}<.05, \mathrm{M}-\mathrm{Min}, \mathrm{SP}=$ Sisihan Piawai, $\eta^{2}($ kecil $=0.2$, sederhana $=0.5$, besar $=0.8)$,

Bumi SS = Bumiputera Sabah dan Sarawak, PSJ=Perkongsian Sejarah, PKT=Perasaan Kekitaan,

PMD=Perkongsian Masa Depan, KST=Kesetiaan, KEN=Keterikatan Emosi Negara, KMT=Komitmen

Analisis terperinci menunjukkan bahawa hanya etnik Melayu dan Bumiputera Sabah dan Sarawak sahaja yang mempunyai pandangan yang berbeza di antara mereka mengenai konsep perkongsian sejarah (perbezaan min=-.269, p<0.05). Etnik Bumiputera Sabah dan Sarawak lebih menekankan makna perkongsian sejarah berbanding etnik Melayu. Hal ini berkemungkinan berkaitan dengan tuntutan MA63 dan situasi politik semasa yang menunjukkan Sabah dan Sarawak mempunyai sejarah pembentukan etos nasional yang berbezan berbanding dengan negeri-negeri di Semenanjung Malaysia. Perasaan kekitaan tidak berbeza di antara etnik Melayu, Cina dan India. Perbezaan yang signifikan dikesan di antara etnik India dan Bumiputera Sabah (perbezaan min $=-.351^{*}, \mathrm{p}<0.05$ ) serta Cina dan Bumiputera Sabah dan Sarawak (perbezaan min $=-.292^{*}, \mathrm{p}<0.05$ ). Hasil analisis ini menunjukkan etnik Bumiputera Sabah dan Sarawak lebih tinggi perasaan kekitaan berbanding etnik India dan Cina. Hal ini dicerminkan oleh faktor kekuatan jiwa dan perasaan sebagai penduduk asal dalam wilayah alam Melayu ini. Dapatan juga menunjukkan tidak terdapat perbezaan yang signifikan antara semua etnik mengenai perkongsian masa depan. Dapatan ini menunjukkan bahawa semua etnik telah sependapat dan bersepakat mahukan negara Malaysia ini direncanakan sebagai tempat kediaman yang baik untuk semua.

Semua etnik tidak menunjukkan perbezaan yang signifikan dalam konteks kesetiaan yang membentuk etos bangsa ini kecuali perbezaan dikesan antara etnik Cina dan Bumiputera Sabah dan Sarawak (perbezaan min $=-.349 *, \mathrm{p}<0.05$ ). Etnik Bumiputera Sabah dan Sarawak didapati menunjukkan kesetian yang lebih tinggi berbanding etnik Cina. Tiada perbezaan yang signifikan juga dikesan antara semua etnik mengenai keterikatan emosi negara. Hal ini menunjukkan bahawa, perasaan terhadap negara ini telah dapat dikongsi bersama dalam setiap perkara. Dalam konteks komitmen, etnik cina didapati menunjukkan perbezaan yang signifikan berbanding etnik Bumiputera Sabah dan Sarawak (perbezaan $\min =-.274^{*}, \mathrm{p}<0.05$ ). Etnik Bumiputera Sabah dan Sarawak menunjukkan komitmen yang lebih tinggi berbanding etnik Cina. Kesemua dapatan analisis post hoc tukey ini menepati dapatan yang dinyatakan dalam Indeks Perpaduan Nasional 2018 yang menunjukkan etnik Bumiputera Sabah dan Sarawak 
DOI: https://doi.org/10.47405/mjssh.v6i7.821

menunjukkan semangat integrasi nasional yang tinggi manakala etnik cina didapati paling rendah memberi komitmen dan penyertaan dalam aktiviti pembinaan etos negara bangsa secara keseluruhan.

Jadual 5: Keputusan Ujian Post Hoc Tukey Konstruk Kesepaduan Sosial mengikut Etnik

\begin{tabular}{|c|c|c|c|c|c|}
\hline Dimensi & Etnik & Etnik & $\begin{array}{r}\text { Perbezaan } \\
\text { Min } \\
\end{array}$ & $\begin{array}{r}\text { Ralat } \\
\text { Piawai }\end{array}$ & Sig. $p<0.05$ \\
\hline \multirow[t]{6}{*}{ Perkongsian Sejarah } & Melayu & Cina & -.103 & .070 & .453 \\
\hline & Cina & India & -.033 & .083 & .977 \\
\hline & India & Bumi SS & -.132 & .099 & .297 \\
\hline & Melayu & India & -.137 & .076 & .273 \\
\hline & Cina & Bumi SS & -.165 & .094 & .297 \\
\hline & Melayu & Bumi SS & $-.269 *$ & .088 & $.013 *$ \\
\hline \multirow[t]{6}{*}{ Perasaan Kekitaan } & Melayu & Cina & .085 & .070 & .620 \\
\hline & Cina & India & .058 & .084 & .900 \\
\hline & India & Bumi SS & $-.351 *$ & .099 & .003 \\
\hline & Melayu & India & .143 & .076 & .242 \\
\hline & Cina & Bumi SS & $-.292 *$ & .095 & .011 \\
\hline & Melayu & Bumi SS & -.208 & .089 & .089 \\
\hline \multirow[t]{6}{*}{ Perkongsian Masa Depan } & Melayu & Cina & .150 & .081 & .247 \\
\hline & Cina & India & -.161 & .096 & .338 \\
\hline & India & Bumi SS & -.117 & .115 & .738 \\
\hline & Melayu & India & -.011 & .088 & .999 \\
\hline & Cina & Bumi SS & -.278 & .109 & .054 \\
\hline & Melayu & Bumi SS & -.128 & .102 & .595 \\
\hline \multirow{6}{*}{ Kesetiaan } & Melayu & Cina & .117 & .073 & .381 \\
\hline & Cina & India & -.237 & .087 & .033 \\
\hline & India & Bumi SS & -.112 & .103 & .701 \\
\hline & Melayu & India & -.120 & .079 & .429 \\
\hline & Cina & Bumi SS & $-.349 *$ & .099 & .002 \\
\hline & Melayu & Bumi SS & -.232 & .092 & .058 \\
\hline \multirow[t]{6}{*}{ Keterikatan Emosi Negara } & Melayu & Cina & .064 & .072 & .809 \\
\hline & Cina & India & -.098 & .086 & .662 \\
\hline & India & Bumi SS & -.118 & .102 & .654 \\
\hline & Melayu & India & -.034 & .078 & .973 \\
\hline & Cina & Bumi SS & -.216 & .097 & .118 \\
\hline & Melayu & Bumi SS & -.152 & .091 & .338 \\
\hline \multirow[t]{6}{*}{ Komitmen } & Melayu & Cina & .092 & .073 & .590 \\
\hline & Cina & India & -.160 & .087 & .255 \\
\hline & India & Bumi SS & -.114 & .103 & .689 \\
\hline & Melayu & India & -.068 & .079 & -.273 \\
\hline & Cina & Bumi SS & $-.274 *$ & .098 & .029 \\
\hline & Melayu & Bumi SS & -.182 & .092 & .197 \\
\hline
\end{tabular}

Nota: Bumi SS = Bumiputera Sabah dan Sarawak

\section{Pembentukan Kesepaduan Nasional Berasaskan Hubungan Etos Bangsa (EB) Ke atas Kesepaduan Sosial (KS)}

Hasil analisis menunjukkan terdapat hubungan yang signifikan antara etos bangsa dan kesepaduan sosial $\left(\mathrm{R}^{2}=0.289 \pm 0.366\right)$ iaitu berlaku peningkatan sebanyak 0.289 unit dalam kesepaduan sosial dengan meningkatnya 1 unit dalam etos bangsa. Hasilnya, kesepaduan nasional akan terbina dengan kesepaduan kedua-dua konstruk ini. Dapatan ini menepati hasil kajian pembangunan Indeks Perpaduan Nasional yang menunjukkan bahawa etos bangsa mempengaruhi kesepaduan sosial untuk membentuk kesepaduan nasional dalam masyarakat di negara kita. 
Jadual 6: Analisis Regresi Linear Mudah Hubungan Etos Bangsa Ke Atas Kesepaduan Sosial

\begin{tabular}{lccccc} 
Pemboleh Ubah & $\mathbf{B}$ & $\boldsymbol{\beta}$ & $\mathbf{t}$ & $\mathbf{p}$ & Fit \\
\hline (pemalar) & 2.02 & & 17.81 & .000 & \\
Etos Bangsa & .43 & .54 & 15.38 & .000 & \\
& & & & & $\mathrm{R} 2=.289^{*}$ \\
\hline
\end{tabular}

Kajian ini menunjukkan bahawa kesepaduan nasional telah terbina dengan baik dalam kalangan penduduk KRT di seluruh Malaysia. Walaupun hanya mengambil satu skop kecil sahaja iaitu kesepaduan nasional berasaskan etos bangsa dan kesepaduan sosial, kajian ini mampu menjelaskan pencapaian yang diinginkan. Umumnya, hampir semua dimensi konstruk kesepaduan sosial dan etos bangsa berbeza secara signifikan antara etnik, namun impaknya adalah kecil. Sungguhpun begitu, kesepaduan nasional adalah terbina dalam kalangan responden KRT walaupun mereka terdiri daripada latar belakang etnik yang berbeza-beza. Hubungan dan pengaruh etos bangsa terhadap kesepaduan sosial dalam membentuk kesepaduan nasional telah menguatkan kesan perkongsian nilai hidup bersama, persamaan pandangan hidup, hubungan horizontal yang merentas pelbagai identiti dalam kehidupan harian penduduk KRT yang dikaji. Proses ini telah membina mikro-solidariti sesama mereka berteraskan kesetiaan dan kecintaan kepada negara (Forrest \& Kearns, 2001; Hyyppä, 2010; Putnam, 2000). Etos bangsa merupakan elemen penting dalam mengukuhkan kesepaduan sosial, dengan penggabungan etos bangsa dan kesepaduan sosial di Malaysia, integrasi nasional menjadi lebih mantap sehingga rakyat mampu mengutamakan kepentingan negara mengatasi kepentingan diri.

\section{Kesimpulan}

Wacana mengenai hubungan antara etnik dalam kalangan masyarakat multietnik Malaysia pada hari ini masih lagi terkesan daripada pengaruh perspektif kolonialisme yang diwarisi dalam bentuk amalan menguruskan kepelbagaian dalam masyarakat menerusi sistem tadbir urus, pembahagian kegiatan ekonomi, dan keterpisahan sosiobudaya serta kawasan penempatan yang digambarkan oleh Furnivall (1948) sebagai ciri-ciri lazim masyarakat plural, mahupun dalam bentuk 'penjajahan minda' melalui penerimaan bulat-bulat pemikiran prejudis dan diskriminasi yang berdasarkan kepada stereotaip sifat dan budaya setiap kumpulan etnik. Kesannya, pemusatan kuasa politik, pembangunan ekonomi dan sosial menjadi tidak seimbang antara kumpulan etnik. Jurang dalam hubungan antara etnik semakin keruh akibat peristiwa-peristiwa pahit yang pernah berlaku dalam masyarakat di negara ini, seperti di era kedatangan Jepun dan rusuhan 13 Mei 1969, terutamanya antara etnik Melayu sebagai kumpulan etnik majoriti dan etnik Cina sebagai kumpulan etnik minoriti terbesar. Mengambil iktibar daripada titik-titik hitam dalam sejarah negara, kerajaan mulai pada ketika itu hingga sekarang, telah meletakkan keutamaan penting untuk memupuk perpaduan dalam masyarakat demi mencapai pembangunan dan kemakmuran bersama dengan mengambil langkah-langkah proaktif memupuk perpaduan dalam masyarakat, dan langkah-langkah pencegahan melalui pemantauan menggunakan indeks. Artikel ini mengambil kira kedua-dua bentuk langkah tersebut dengan mengkaji keterbinaan perpaduan dalam kalangan penduduk KRT di seluruh negara melalui satu kajian yang diadaptasikan daripada model IPNas 2018 dan diubahsuai konstruk-konstruknya mengikut cabaran-cabaran dalaman negara yang dihadapi masyarakat multietnik Malaysia dalam tahun 2018 hingga 2019.

Program KRT merupakan salah satu usaha kerajaan yang berjaya dilaksanakan dalam satu jangka masa panjang sejak tahun 1975 hingga sekarang. Usaha kerajaan untuk menyatupadukan masyarakat di peringkat akar umbi melalui pelaksanaan program tersebut yang bersifat 'meraikan kepelbagaian' telah membuahkan hasil apabila kesepaduan nasional didapati terbina dengan baik lagi kukuh dalam kalangan penduduk daripada pelbagai latar belakang yang tinggal di KRT di seluruh negara. Masyarakat multietnik Malaysia kian bergerak mendekati perpaduan yang diidam-idamkan semua pihak. Interaksi 
etos bangsa dan kesepaduan sosial membawa kepada terbinanya kesepaduan nasional yang lebih utuh, sehinggakan rakyat mampu mengutamakan kepentingan negara melebihi kepentingan diri. Dalam konteks KRT yang dikaji, pembentukan kesepaduan nasional melalui pendekatan lembut (soft approach) menjadikan pembinaan ciri kolektif nasional berlandaskan ideologi kebangsaan dan nilai-nilai murni sepunya diterapkan secara terancang menerusi aktiviti-aktiviti yang berkait rapat dengan kehidupan seharian. Lantaran itu, pemerkasaan program KRT melalui Akta Rukun Tetangga 2012 dan Dasar Perpaduan Negara 2021 dilihat berpotensi besar untuk menjadi alat penyatupaduan masyarakat multietnik secara lebih menyeluruh dan tersusun untuk mengukuhkan perpaduan di Malaysia.

\section{Rujukan}

Abd Hadi, M. S., \& Norwahidah, Z. (2013). Panduan pengurusan Rukun Tetangga. JPNIN.

Alatas, S. H. (1971). Rukunegara. Pacific Community, 2(1-4), 800-808.

Alias, M. (2005). Managing Rukun Tetangga in a multiracial society. In Muhammad Kamarul, K., \& Zaharah, H. (Eds.). Readings on ethnic relations in a multicultural society: Promoting national unity and the practice of noble values (pp. 115-120). Fakulti Pendidikan, Universiti Putra Malaysia.

Babbie, E. (2010). The practice of social research (12th ed.). Wadsworth Cengage Learning.

Bernard, P. 1999. Social cohesion: A critique. Canadian Policy Research Network.

Budi Anto. M. T., Mohd Sohaimi, E., \& Mohd Azri, I. (2020). Hubungan kaum dalam kawasan Rukun Tetangga (KRT) di Pantai Barat Sabah. Malaysian Journal of Social Sciences and Humanities, $5(11), 147-158$.

Cohen, J. (1990). Things I have learned (so far). American Psychologist, 45(12), 1304-1312.

Ehmer, E., \& Kothari, A. (2020). Malaysia and the Rohingya: media, migration, and politics. Journal of Immigrant \& Refugee Studies, DOI: 10.1080/15562948.2020.1821274

Ezhar, T., Yee, W., Fazilah, I., Azimi, H., Zainal, A. B., Wong, S. L. \& Mansor, M. N. (2005). The relationship of exposure to news media with attachment to the national ethos. Pertanika Journal Social Sciences \& Humanities 13(2), 187-198.

Faris Isma, M. A. R., Muhamad Sayuti, H. Y., \& Nizamuddin, A. (2017). The role of Neighbourhood Watch in reducing crimes in the community. The European Proceedings of Social \& Behavioural Sciences, 52, 808-814.

Forrest, R., \& Kearns, A. (2001). Social cohesion, social capital and the neighbourhood. Urban Studies, $38(12), 2125-2143$.

Franck, A. K. (2019). The 'street politics' of migrant il/legality: navigating Malaysia's urban borderscape. Asia Pacific Viewpoint, 60(1), 14-23.

Furnivall, J. S. (1948). Colonial policy and practice: A comparative study of Burma and Netherlands India. Cambridge University Press.

Hyyppä, M.T. (2010). Healthy ties: Social capital, population health and survival. London: Springer.

Jabatan Perangkaan Malaysia. (2019, December 24). Siaran akhbar Indeks Kesejahteraan Rakyat Malaysia, 2018. https://www.dosm.gov.my/v1/index.php?r=column/pdfPrev\&id=NWhJYlhTK 0N3VCs3U31NVXhaeCtYZz09

Jabatan Perpaduan Negara dan Integrasi Nasional (JPNIN). (2018). Laporan perpaduan tahunan 2018. Jabatan Perpaduan Negara dan Integrasi Nasional.

Jabatan Perpaduan Negara dan Integrasi Nasional (JPNIN). (2021). Panduan pengurusan dan pentadbiran Rukun Tetangga. Kementerian Perpaduan Negara.

Jabatan Perpaduan Negara dan Integrasi Nasional (PERPADUAN) \& Institut Kajian Etnik (KITA), UKM. (2019). Laporan akhir Indeks Perpaduan Nasional, 2018. Jabatan Perpaduan Negara dan Integrasi Nasional.

Jenson, J. (1998). Mapping social cohesion: The state of Canadian. Canadian Policy Research Network. Kementerian Perpaduan Negara. (2021). Pelan pemerkasaan kepimpinan komuniti Rukun Tetangga 2021-2030. Kementerian Perpaduan Negara.

Khairol, A. K. (2014). Impak etnisiti, tadbir urus dan etika kerja terhadap kesepaduan sosial Polis Diraja Malaysia (PDRM) (PhD thesis). Universiti Kebangsaan Malaysia.

Lee, J. C. H. (2018). Outrage in Malaysia: the politics of taking offence. East Asia, 35, 249-265.

Mahani, A. B. (2008). Semangat kejiranan. Pustaka Buana. 
Mahathir, M. (1992, January 31). Bangsa Malaysia yang bersepadu menjelang tahun 2020. Teks Ucapan di Majlis Makan Malam anjuran Kelab Harvard Malaysia, Kuala Lumpur.

Mansor, M. N. (2012). Kerencaman sosial dan penipisan batas etnik: kepelbagaian etnik dan perkongsian hidup bersama di Malaysia. Penerbit UKM.

Mansor, M. N., Abdul Rahman, A. A., \& Mohamad Ainuddin, I. L. (2006). Hubungan etnik di Malaysia. Prentice Hall Pearson Malaysia.

McLaughlin, T. (2005). The educative importance of ethos. British Journal of Educational Studies 53(3), 306-325.

Mohd Sobhi, I. (2021). Kajian defisit sosial di Malaysia. Paper presented at the Wawasan Kemakmuran Bersama: Mengurus Defisit Sosial di Malaysia.

Mohd Mahadee, I. (2015). Sosialisasi politik, etos nasional dan negara-bangsa: kajian pendidikan sivik dan Program Latihan Khidmat Negara (PLKN) dalam kalangan mahasiswa Universiti Putra Malaysia (UPM) (PhD thesis). Universiti Kebangsaan Malaysia.

Mohd Syariefudin, A., Mohd Mahadee, I., \& Mansor, M. N. (2013). Kesepaduan sosial dan kejiranan di kawasan Rukun Tetangga. Jurnal Kinabalu, 19, 53-75.

Mohd Taib, D. (2009). Keberkesanan program Rukun Tetangga dalam memupuk perpaduan dan integrasi nasional. Jurnal Perpaduan Jabatan Perpaduan Negara dan Integrasi Nasional (JPNIN), $1(1), 33-48$.

Mustafa, I. (2020). Malaysia in 2019: enduring stability in a chaotic year. Asian Survey, 60(1), 100-108.

Mustapha, W. Z. W., Gill, S. S., \& Ismail, I. A. (2016). Penglibatan jiran muda dalam aktiviti Rukun Tetangga di Daerah Hulu Langat, Selangor. Malaysian Journal of Youth Studies, 14(6), 261-276.

Nor Hashimah, J., Shamsul, A. B., Mustafa, O. \& Mansor, M. N. (2003). Pengasimilasian identiti nasional dan etos bangsa di kalangan rakyat Malaysia: Satu kajian sosio-budaya. Laporan Penyelidikan. Institut Alam dan Tamadun Melayu, Universiti Kebangsaan Malaysia.

Nor Hashimah, J., Shamsul, A. B., Mustafa, O. \& Mansor, M. N. (2004). Identiti nasional dan etos bangsa. Dewan Budaya 26(8), 9-13.

Norwahidah, Z., \& Novel, L. (2016). Makna rasa selamat komuniti Malaysia dalam Program Skim Rondaan Sukarela: Kajian kes KRT Taman Putera Jaya, Kota Kinabalu, Sabah. Geografia, 12(5), 22-32.

Oren, N. (2009). The Israeli ethos of conflict 1967-2006. George Mason University.

Prashanta, W. (2018). ICERD and old politics: new twists in post-election Malaysia? Nanyang Technological University.

Putnam, R. D. (2000). Bowling alone: The collapse and revival of American community. Simon and Schuster.

Rashid, S. (2004). Sumbangan Rukun Tetangga 21 dalam perpaduan negara dan pembangunan komuniti. In Dani, S. (Ed.), Pembangunan komuniti: dasar, konsep, strategi dan isu di Malaysia (pp. 1-3). Penerbit Universiti Utara Malaysia.

Schwaninger, M. (2006). Intelligent organizations powerful models for systemic management. Springer.

Shamsul, A. B., \& Anis, Y. Y. (2014). Perpaduan, kesepaduan, penyatupaduan: Satu negara, satu kata akar, tiga konsep keramat. Institut Kajian Etnik.

Shamsul, A. B. (Ed.). (2012). Modul hubungan etnik (2nd ed.). Institut Kajian Etnik.

Shamsul, A. B. (2009). Managing a 'stable tension' ethnic relationship in Malaysia: Re-examined. Institut Kajian Etnik.

Shamsul, A. B. (2014). Perpaduan, kesepaduan dan penyatupaduan: satu negara, satu kata akar, tiga konsep keramat. Paper presented at the Persidangan Pemantapan Citra Kenegaraan: Perkongsian Pengalaman, 19-21 Januari, Universiti Kebangsaan Malaysia.

Ufen, A. (2020). Opposition in transition: pre-electoral coalitions and the 2018 electoral breakthrough in Malaysia. Democratization, 27(2), 167-184.

Vision Humanity. (2019). Global Peace Index 2019. Institute for Economics and Peace.

Wan Zumaiza, W.M., Gill, S.S., \& Ismi, A.I. (2016). Penglibatan jiran muda dalam aktiviti Rukun Tetangga di daerah Hulu Langat, Selangor. Malaysian Journal of Youth Studies, 14(6), 261-276. 